\title{
THE ACTION OF HYDROCORTISONE IN SYNOVIAL INFLAMMATION ${ }^{1,2}$
}

\author{
By RALPH A. JESSAR, ${ }^{3}$ MARY ANN GANZELL, AND CHARLES RAGAN \\ (From the Department of Medicine, Columbia University College of Physicians and Surgeons, \\ and the Edward Daniels Faulkner Arthritis Clinic of the Presbyterian Hospital, \\ New York, N. Y.)
}

(Submitted for publication December 5, 1952; accepted February 25, 1953)

The anti-inflammatory effects of systemic cortisone (compound $E$ ) have been amply demonstrated in the treatment of rheumatoid arthritis $(1,2)$ and in experimental models in animals $(3,4)$. Similarly, the local use of cortisone in the treatment of inflammatory conditions of the eye $(5,6)$ and the effectiveness of this hormone in blocking the host reaction to a turpentine abscess (4) have given eloquent testimony to its local effect.

Compound F (hydrocortisone) acetate has been demonstrated by Hollander, Brown, Jessar, and Brown (7) to lower joint temperatures and to exert a clinically beneficial effect when injected into the joints of patients with either rheumatoid or degenerative arthritis. This phenomenon was not noted with the use of cortisone. These clinical findings have been confirmed repeatedly $(8,9$, 10) and additional experimental data have accumulated (11) to suggest the efficacy of hydrocortisone acetate as a potent anti-inflammatory agent for local use.

In an attempt to obtain a further clue to the explanation of the clinical response observed with intra-articular compound $\mathrm{F}$ acetate, we have studied changes in joint fluid following treatment with this agent.

\section{METHODS}

Synovial fluid was obtained from the knees of patients with rheumatoid arthritis before and one to seven days following intra-articular injection of 25 to $37.5 \mathrm{mgm}$. of hydrocortisone acetate. Viscosity of the fluids obtained was measured in a $5 \mathrm{cc}$. Ostwald viscosimeter at the standard temperature of $21^{\circ} \mathrm{C} . \pm 1^{\circ} \mathrm{C}$. Hyaluronic acid concentration was determined by the method of Meyer (12) modified (13) by eliminating the gelatin and incubation of substrate with $1 / 100$ of TRU of purified testicu-

1 Supported in part by grant from the Masonic Foundation for Medical Research and Human Welfare.

2 Hydrocortisone supplied through the courtesy of Merck \& Company, Rahway, N. J.

${ }^{3}$ Fellow of the Arthritis and Rheumatism Foundation. lar hyaluronidase for $30 \mathrm{~min}$. at $37^{\circ} \mathrm{C}$. One tube of fluid is incubated with $10 \mathrm{TRU}$ of hyaluronidase and if turbidity remains, this is subtracted from the turbidity produced in the unknown. The turbidity in the blank only occasionally appears and is not due to hyaluronate. Total protein was estimated by a specific gravity gradient method $(14,15)$.

Certain of the synovial fluid specimens were studied by Tiselius electrophoresis at an ionic strength of 0.2 in $0.02 \mathrm{M}$ phosphate buffer at $\mathrm{pH} 7.4 .4$

\section{RESULTS}

All patients in this study showed a definite beneficial effect of varying duration, characterized locally by decrease in pain, swelling and other signs of inflammation.

Twenty-one pairs of observations in seven patients were made before and one to seven days after treatment with intra-articular hydrocortisone. We have measured total protein, relative viscosity, hyaluronic acid concentration and derived from the latter two measurements, a factor which serves as an expression of the degree of polymerization of the hyaluronic acid present (16). An increase in this factor reflects the presence of a more highly polymerized hyaluronate.

The findings which are listed in Table I reveal that, following local use of $F$ acetate in the knees in 21 instances, no definite pattern of response was noted in the total protein. In 14 instances, however, there was an appreciable increase in relative viscosity with, in 13 instances, a rise in a hyaluronic acid concentration. This rise in hyaluronic acid concentration usually did not vary directly proportionately to the $\log$ of the viscosity. Hence, in the fourteen pairs of observations noted, an increase in the factor was apparent in twelve; a decrease in one and no change in the other. Where viscosity was not increased (Table I), the time lag between hormonal administration and withdrawal of fluid is the greatest, and the possibility exists that the inflammatory process may have recurred.

\footnotetext{
4 Done through the courtesy of Dr. Dan Moore.
} 
TABLE I

Changes in joint fluids of rheumatoid arthritis patients following the use of hydrocortisone

\begin{tabular}{|c|c|c|c|c|c|}
\hline \multirow[b]{2}{*}{ Pt. } & \multirow{2}{*}{$\begin{array}{l}\text { No. of days } \\
\text { following } \\
\text { each } \\
\text { treatment } \\
\text { with } F^{*}+\end{array}$} & \multicolumn{4}{|c|}{ Change in } \\
\hline & & $\begin{array}{l}\text { Total } \\
\text { protein } \\
\text { gm. \% }\end{array}$ & $\begin{array}{c}\text { Relative } \\
\text { viscosity } \\
\times H_{20}\end{array}$ & $\begin{array}{l}\text { Hyaluronic } \\
\text { acid } \\
\text { mgm./cc. }\end{array}$ & $\begin{array}{c}\text { Factor } \\
\text { log visc./HA conc. }\end{array}$ \\
\hline \multirow[t]{2}{*}{ J.W.t } & $\begin{aligned} \text { Rt. } 2 \\
3 \\
4 \\
2 \\
7\end{aligned}$ & $\begin{array}{l}4.2-4.3 \\
4.3-3.8 \\
4.2-4.3 \\
4.9-4.2 \\
4.1-4.5\end{array}$ & $\begin{array}{r}12.9-256.2 \\
14.9-125.5 \\
10.5-19.8 \\
8.7-20.0 \\
20.0-11.0\end{array}$ & $\begin{array}{l}.136-.274 \\
.136-.213 \\
.102-.146 \\
.092-.076 \\
.076-.060\end{array}$ & $\begin{array}{r}8.2-8.8 \\
8.8-9.9 \\
10.6-8.9 \\
10.2-17.0 \\
17.0-17.2\end{array}$ \\
\hline & $\begin{array}{r}\text { Lt. } 2 \\
7 \\
7\end{array}$ & $\begin{array}{l}4.8-3.9 \\
3.9-4.8 \\
4.7-5.0\end{array}$ & $\begin{array}{r}7.3-36.3 \\
36.3-12.6 \\
12.6-13.4\end{array}$ & $\begin{array}{l}.076-.095 \\
.095-.067 \\
.067-.070\end{array}$ & $\begin{array}{l}11.4-16.4 \\
16.4-16.4 \\
16.4-15.9\end{array}$ \\
\hline J. L.t & 2 & $5.0-4.7$ & $5.7-51.2$ & $.057-.137$ & $13.3-12.5$ \\
\hline R.F. & 7 & $4.5-3.7$ & $30.6-140.3$ & $.128-.183$ & $11.6-12.3$ \\
\hline \multirow[t]{2}{*}{ M. K. } & Rt. $\begin{array}{l}2 \\
2\end{array}$ & $\begin{array}{l}5.2-4.9 \\
4.7-4.7\end{array}$ & $\begin{array}{l}35.5-156.8 \\
21.5-30.9\end{array}$ & $\begin{array}{l}.132-.158 \\
.115-.113\end{array}$ & $\begin{array}{l}11.7-13.9 \\
11.6-13.2\end{array}$ \\
\hline & 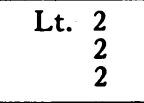 & $\begin{array}{l}5.2-4.8 \\
4.6-4.8 \\
4.6-4.7\end{array}$ & $\begin{array}{l}28.7-73.3 \\
43.6-201.6 \\
41.3-80.3\end{array}$ & $\begin{array}{l}.100-.117 \\
.149-.182 \\
.114-.111\end{array}$ & $\begin{array}{l}14.6-15.9 \\
11.0-12.7 \\
14.3-17.3 \\
\end{array}$ \\
\hline G. W. & 1 & $4.4-5.1$ & $7.5-13.5$ & $.051-.074$ & $17.2-15.3$ \\
\hline E. W. & 2 & $5.3-4.6$ & $13.6-88.2$ & $.065-.111$ & $17.4-17.6$ \\
\hline \multirow[t]{2}{*}{ H. T.f } & Rt. $\begin{array}{l}1 \\
1\end{array}$ & $\begin{array}{l}6.5-6.0 \\
6.1-5.4\end{array}$ & $\begin{array}{l}40.6-86.1 \\
35.3-196.5\end{array}$ & $\begin{array}{l}.130-.138 \\
.162-.203\end{array}$ & $\begin{array}{r}12.3-14.0 \\
9.5-11.2\end{array}$ \\
\hline & $\begin{array}{ll}\text { Lt. } & 1 \\
1\end{array}$ & $\begin{array}{l}6.6-6.3 \\
5.9-5.4\end{array}$ & $\begin{array}{l}43.9-92.1 \\
35.7-126.4\end{array}$ & $\begin{array}{l}.140-.159 \\
.161-.193\end{array}$ & $\begin{array}{r}11.7-12.3 \\
9.6-10.9\end{array}$ \\
\hline
\end{tabular}
knee.

* Compound F acetate (17-hydroxycorticosterone-21-acetate) in dose of 25 or $\mathbf{3 7 . 5}$ mgm. intra-articularly into the

$\dagger$ Each trial represents a pair of individual observations without specific temporal relationship between trials. The shortest interval between trials was 7 days.

$\ddagger$ These patients were simultaneously on systemic therapy with cortisone or ACTH.

Four pairs of the fluids studied were examined electrophoretically; these studies reflected the same changes as were noted by measure of total protein and hyaluronic acid. In three of the pairs studied, a 20 to 25 per cent decrease was seen in the total area of electrophoretic protein pattern after compound $\mathrm{F}$ acetate as compared to the pretreatment pattern with relatively the same decrease in all protein components. In each case, a fast moving component, having the same electrophoretic mobility as hyaluronic acid isolated from synovial fluid, ${ }^{5}$ was seen to remain the same or to increase slightly.

\section{COMMENT}

In the course of our observations, it became apparent that the use of intra-articular compound $F$ was clinically beneficial. The response was prompt even in those individuals in whom joint fluid stud-

\footnotetext{
5 Supplied through the courtesy of Dr. Karl Meyer.
}

ies revealed no change in hyaluronic acid concentration.

The total protein, which showed no consistent change, apparently cannot be regarded as an indication of the inflammatory state of the synovia.

Normal joint fluid has a high viscosity probably due, in most part, to hyaluronic acid associated with a relatively low concentration of this polysaccharide $(17,18)$, which results in a high "factor of polymerization." It would seem that the relatively high viscosity of synovial fluid following treatment with intra-articular $F$ acetate is related to a change both in the character and the concentration of the hyaluronate present. Thus, the changes in joint fluid induced by the local administration of this hormone reflect a trend toward the normal state. To produce this trend, the hormone must act either upon the cells secreting the hyaluronate, upon the permeability of the vascular synovial barrier or by inhibition of hyaluronidase 
production. This latter possibility is unlikely since hyaluronidase has not been demonstrated in synovial fluid. There was no distinct trend in the direction of change of total protein of the synovial fluid while viscosity changes occurred and, therefore, a change in permeability may be regarded as inoperative or, at most, secondary in effect. More important and not explained by a decrease in permeability is the evidence of qualitative as well as quantitative change in the hyaluronate as indicated by increases in both viscosity and the "polymerization factor." We are left, therefore, with the conclusion that the site of action of this agent is the synovial tissue where, by a suppression of inflammation, the cells of the synovial membrane (which are believed to secrete the hyaluronate of synovial fluid $[19,20]$ ) are permitted to secrete a more normal product.

\section{CONCLUSIONS}

1. Intra-articular compound $F$ acetate produced a definite clinical anti-inflammatory response.

2. This response was reflected by changes in the joint fluid with an increase in relative viscosity, hyaluronic acid concentration and, in most instances, an increase in the factor of polymerization. Changes in protein concentration were inconsistent.

3. The site of action of intra-articular compound $\mathrm{F}$ acetate is probably at the synovial membrane.

\section{ACKNOWLEDGMENTS}

The authors wish to express their thanks to Dr. Karl Meyer for his advice.

\section{REFERENCES}

1. Hench, P. S., Slocumb, C. H., Polley, H. F., and Kendall, E. C., Effect of cortisone and pituitary adrenocorticotropic hormone (ACTH) on rheumatic diseases. J. A. M. A., 1950, 144, 1327.

2. Boland, E. W., and Headley, N. E., Oral use of cortisone acetate. J. A. M. A., 1951, 145, 8.

3. Spain, D. M., Molomut, N., and Haber, A., Biological studies on cortisone in mice. Science, 1950, 112, 335.

4. Taubenhaus, M., and Amromin, G. D., The effects of the hypophysis, thyroid, sex steroids, and the adrenal cortex upon granulation tissue. J. Lab. \& Clin. Med., 1950, 36, 7.
5. Leopold, I. H., Purnell, J. E., Cannon, E. J., Steinmetz, C. G., and McDonald, P. R., Local and systemic cortisone in ocular disease. Am. J. Ophth., 1951, 34, 361.

6. Duke-Elder, Sir Stewart, and Ashton, N., Action of cortisone on tissue reactions of inflammation and repair with special reference to the eye. Brit. J. Ophth., 1951, 35, 695.

7. Hollander, J. L., Brown, E. M., Jr., Jessar, R. A., and Brown, C. Y., Hydrocortisone and cortisone injected into arthritic joints. J. A. M. A., 1951, 147, 1629.

8. Stevenson, C., Discussion in Hollander, J. L., Brown, E. M., Jr., Jessar, R. A., and Brown, C. Y., Comparative effects of compound F (17-hydroxycorticosterone) and cortisone injected into rheumatoid arthritis joint. Ann. Rheumat. Dis., 1951, 10, 473.

9. Ziff, M., Scull, E., Ford, D., McEwen, C., and Bunim, J. J., Effects of intra-articular hydrocortisone on clinical course, aminotripeptidase activity and other changes in synovial fluid in rheumatoid arthritis. Ann. Rheumat. Dis., 1952, 11, 301.

10. Breck, C. A., and Breck, R. W., The intra-articular use of hydrocortisone. Meriden Hosp. Bull., 1952, 6, 39.

11. Goldman, L., Preston, R. H., Rockwell, E., and Baskett, J., Inhibition of tuberculin reaction by local injection of compound F. J. A. M. A., 1952, 150, 30.

12. Meyer, K., The biological significance of hyaluronic acid and hyaluronidase. Physiol. Rev., 1947, 27, 335.

13. Meyer, K., Personal communication.

14. Lowry, O. H., and Hastings, A. B., Histochemical changes associated with aging. I. Methods and calculations. J. Biol. Chem., 1942, 143, 257.

15. Lowry, O. H., and Hunter, T. H., The determination of serum protein concentration with a gradient tube. Ibid., 1945, 159, 465.

16. Ragan, C., and Meyer, K., The hyaluronic acid of synovial fluid in rheumatoid arthritis. J. Clin. Invest., $1949,28,56$.

17. Bauer, W., Ropes, M. W., and Waine, H., The physiology of articular structures. Physiol. Rev., 1940, 20, 272.

18. Ragan, C., The physiology of the connective tissue (Loose Areolar). Ann. Rev. Physiol., 1952, 14, 51.

19. Coggeshall, H. C., The synovial fluid, in Comroe, B. I., Arthritis and Allied Conditions, edited by Hollander, J. L. Lea \& Febiger, Philadelphia, 1952, 4th ed., p. 52.

20. Ragan, C., Viscosity of normal human synovial fluid. Proc. Soc. Exper. Biol. \& Med., 1946, 63, 572. 